\title{
Flow Injection Spectrophotometric Determination of Baclofen in Pharmaceutical Formulation Using Prussian Blue Reaction
}

\author{
Ghadah Fadhil \\ Department of Chemistry, College of Science, University of Baghdad, Baghdad-Iraq. \\ E-mail: ghadaalhakim@yahoo.com
}

\begin{abstract}
A simple, rapid and sensitive spectrophotometric method for the determination of baclofen in pharmaceutical preparations were developed by combining a spectrophotometric detector with Flow injection analysis. This method based on the oxidation of iron (II) to iron (III) by baclofen and formation of complex between iron (III) and potassium hexacyano ferrate (II) in acidic solution. The absorbance from prussian blue dye is recorded at $700 \mathrm{~nm}$. Chemical and physical parameters of this system were investigated. The linearity of baclofen is ranged from $(0.05-25)$ mmol.L ${ }^{-1}$ with correlation coefficient $r=0.9972$. The limit of detection $\left(\mathrm{S} / \mathrm{N}=3\right.$ ) was equaled $0.01 \mathrm{mmol} . \mathrm{L}^{-1}$ the L.O.Q was $1.05 \mathrm{mmol} . \mathrm{L}^{-1}$ and a relative standard deviation for 6 replicate determinations of baclofen in $10 \mathrm{mmol} . \mathrm{L}^{-1}$ solution was $1.3 \%$ using $100 \mu \mathrm{L}$ sample volume. The proposed method was successfully applied to the determination of baclofen in pharmaceutical formulation with recovery $99 \%$. Using paired t-test it was shown that there was no significant difference between the proposed method and official method on that basis the proposed method can be accepted as an alternative analytical method. [DOI: 10.22401/JNUS.20.1.03]
\end{abstract}

Keywords: Baclofen (BCF), Flow injection analysis, Spectrophotometric, Prussian blue (PB).

\section{Introduction}

Baclofen (BCF) (4-amino-3-p-chlorophenyl butyric acid) Fig.(1) is a chemical analogue of $\gamma$-amino butyric acid (GABA) and is widely used as a skeletal muscle relaxant in the treatment of spastic disorders ${ }^{[1]}$, which is widely used in the treatment spastcity resulting from multiple sclerosis, muscle spasms, muscular rigidity and spinal cord injuries, where pain persist predominantly, in such cases the quick onset of action is of prime importance $^{[2]}$.

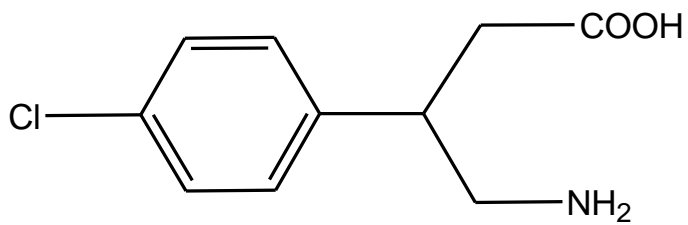

Fig.(1): Chemical structure of Baclofen.

Baclofen is official drug in B.P and U.S.P ${ }^{[3,4]}$. Baclofen is available in oral and intravenous formulation. Though the conventional oral tablets are widely used, they suffer from a few practical drawbacks such as it is non-suitability when quick onset of action is required ${ }^{[5]}$. In efficacy in treatment of different diseases it is important to determine the amounts of Baclofen in the tablets. Several methods reported for determination of Baclofen biological fluids and pharmaceutical formulation, based on RP-HPLC with UV detection $^{[6]}$, RF-HPLC - PDA for simultaneous of Baclofen and tiganidine ${ }^{[7]}$, HPLC with fluorescence detection ${ }^{[8]}, \quad$ LC-mass spectrometry ${ }^{[9]}$ and uv-spectrometry ${ }^{[10]}$. There is a little study to make determination of Baclofen by colorimetric method by spectrophotometry ${ }^{[11-13]}$.

Prussian blue (PB) is obtained by the addition of $\mathrm{Fe}$ (III) salt to a solution of $\left[\mathrm{Fe}(\mathrm{CN})_{6}\right]^{4-}$. Turn bults blue (TB) is formed by the addition of $\mathrm{Fe}$ (II) salt to a solution of $\left[\mathrm{Fe}(\mathrm{CN})_{6}\right]^{3-}$. It's known appreciated that TB and $\mathrm{PB}$ are the same because of the rapidity of electron exchange through a $\mathrm{Fe}-\mathrm{CN}-\mathrm{Fe}$ linkage. The exact hue depends on the method of prepration, which dictate the energy of the transfer of electrons from $\mathrm{Fe}(\mathrm{II})$ to $\mathrm{Fe}(\mathrm{III})^{[14]}$, this work was applied to determination of paracetamol using merging zone-FIA ${ }^{[15]}$.

The work conducted in this research relies on the use of baclofen (Lioresal) as an oxidant for the prepared $\mathrm{Fe}$ (II) ion to form $\mathrm{Fe}$ (III), then the formed $\mathrm{Fe}(\mathrm{III})$ meets with $\left[\mathrm{Fe}(\mathrm{CN})_{6}\right]^{4-}$ to form prussian blue (PB) which is $\mathrm{Fe}_{4}$ $\left[\mathrm{Fe}(\mathrm{CN})_{6}\right]_{3}$ that is blue in color, then passes 
through flow cell where it irradiated with $700 \mathrm{~nm}$ LED at variable intensity using photo silicon diode as detector ${ }^{[15]}$.

\section{Experimental}

\section{Reagents and chemicals}

\section{Chemicals}

All chemicals used were of analytical reagent grade. Deionizer water was used throughout this work.

BCF stock standard solution, $\mathrm{C}_{10} \mathrm{H}_{12} \mathrm{ClNO}_{2}$, 213.67 g.mol ${ }^{-1}$, Syria, $100 \mathrm{mmol} . \mathrm{L}^{-1}$ was prepared by dissolving $2.1367 \mathrm{~g} / 100 \mathrm{~mL}$ distilled water. Iron (II)(100 mmol.L $\left.\mathrm{L}^{-1}\right)$ was prepared by dissolving $13.901 \mathrm{~g}$ in $500 \mathrm{ml}$ distilled water. A stock $\left(100 \mathrm{mmol} . \mathrm{L}^{-1}\right)$ solution of potassium hexacyano ferrous (II) $\mathrm{K}_{4}\left[\mathrm{Fe}(\mathrm{CN})_{6}\right]$ (Fluka $\mathrm{AG}$ ) was prepared by dissolving $18.3925 \mathrm{~g}$ in $500 \mathrm{~mL}$ distilled water. Nitric acid $\left(1 \mathrm{~mol} . \mathrm{L}^{-1}\right)$, dilute $128 \mathrm{~mL}$ of $70 \% \mathrm{HNO}_{3}$ with water to $2 \mathrm{~L}$, sulphuric acid (1 mol.L $\mathrm{L}^{-1}$ ), dilute $11 \mathrm{~mL} / 2 \mathrm{~L}$ of $96 \% \mathrm{H}_{2} \mathrm{SO}_{4}$, $\mathrm{HCl}\left(1 \mathrm{~mol} . \mathrm{L}^{-1}\right)$ dilute $176.50 \mathrm{~mL} / 2 \mathrm{~L}$ of $35 \%$ $\mathrm{HCl}$.

The flow system used for the determination of BCF, shown schematically in Fig.(2). A peristaltic pump: three channels (Ismatec Switzerland). The drug solution was injected through the six-way injection valve (IDEX corporation, USA) with sample loop $(0.7 \mathrm{~mm}$ i.d., Teflon, variable lengths), the source $(5 \mathrm{~mm}$ O.D, low current, Round LED, red light), the detector (Siemens, silicon photodiode) and the amplification unit ${ }^{[15]}$. Gragh $\mathrm{x}-\mathrm{t}$ recorder (1023-kompen sogragh, Siemens, Germany).

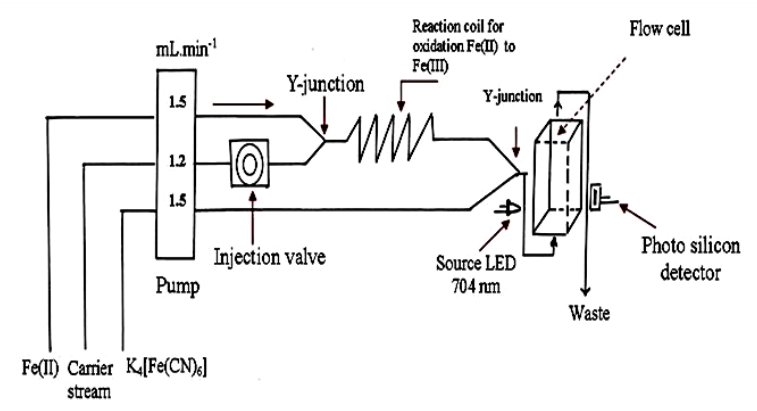

Fig.(2): Schematic diagram of flow injection analysis system for the determination of $B C F$.

\section{Methodology}

The whole manifold system for $\mathrm{BCF}$ determination via: $\mathrm{BCF}-\mathrm{Fe}(\mathrm{II})-\left[\mathrm{Fe}(\mathrm{CN})_{6}\right]^{4-}$ $\mathrm{H}_{3} \mathrm{O}^{+}$system shown in Fig.(2). The manifold system is composed of three lines: First line supplied with $\mathrm{Fe}(\mathrm{II})$ ion $\left(5 \mathrm{mmol} . \mathrm{L}^{-1}\right)$ at 1.5 mL.min ${ }^{-1}$, while the second represented the carrier stream (acidic medium) leading to the injection valve which allows the use of $100 \mu \mathrm{L}$ and a flow rate of $1.2 \mathrm{~mL} \cdot \mathrm{min}^{-1}$. Both line meet at Y-injection; with an outlet for reactant product $\mathrm{Fe}$ (II), which is loaded to loop $(100 \mathrm{~cm})$ for completion of reaction and oxidation of $\mathrm{Fe}$ (II) to $\mathrm{Fe}$ (III) by $\mathrm{BCF}$. The third line supplied with $\mathrm{K}_{4}$ $\left[\mathrm{Fe}(\mathrm{CN})_{6}\right]\left(1 \mathrm{mmol} . \mathrm{L}^{-1}\right)$ at $1.5 \mathrm{~mL} \cdot \mathrm{min}^{-1}$ flow rate. Both out coming lines meet at the $\mathrm{Y}$ injection for completion of reaction between produced $\mathrm{Fe}(\mathrm{III})$ and $\left[\mathrm{Fe}(\mathrm{CN})_{6}\right]^{4-}$ to form colorful blue complex, $\mathrm{Fe}_{4}\left[\mathrm{Fe}(\mathrm{CN})_{6}\right]_{3}$ then passes through flow cell where it irradiated with light emitting diode having $704 \mathrm{~nm}$ with a variable intensity monitored and a photo silicon diode as a detector ${ }^{[15]}$ and shown in Fig.(2). UV spectra were measured with an uvvis (CARY 100 conc.) spectrophotometer (Japan). A proposed mechanism of oxidation of $\mathrm{Fe}$ (II) by $\mathrm{BCF}$ in acidic medium to $\mathrm{Fe}$ (III) is presented in (scheme-1), that was proved practically and spectroscopically. 


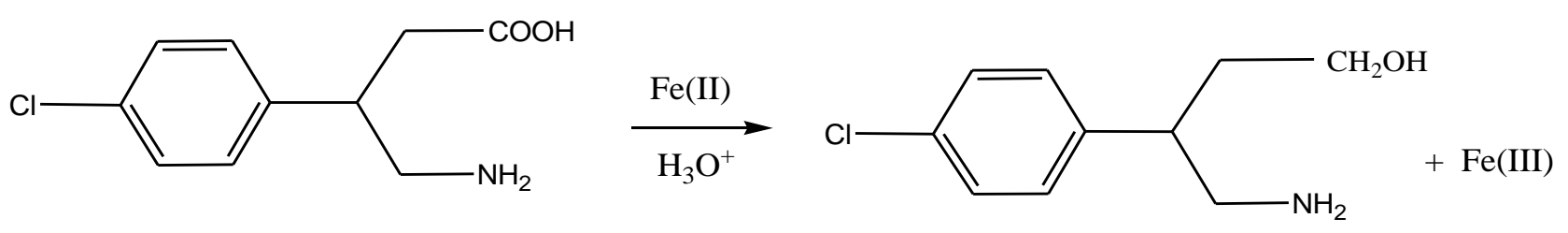

$$
\mathrm{Fe}(\mathrm{III})+\left[\mathrm{Fe}(\mathrm{CN})_{6}\right]^{4-}
$$$$
\mathrm{Fe}_{4}\left[\mathrm{Fe}(\mathrm{CN})_{6}\right]_{3}
$$

Prusssian Blue (BP)

\section{Scheme (1): Proposed mechanism of reaction between BCF and Fe(II) in acidic medium.}

\section{Results and discussion}

\section{Spectroscopic study of P.B complex}

Using preliminary experimental concentrations of the chemicals used in the main reaction where as following : $\mathrm{Fe}(\mathrm{II})\left(8 \mathrm{mmol} . \mathrm{L}^{-1}\right), \mathrm{K}_{4}$ $\left[\mathrm{Fe}(\mathrm{CN})_{6}\right]\left(5 \mathrm{mmol} . \mathrm{L}^{-1}\right)$ and BCF $\left(10 \mathrm{mmol}^{-\mathrm{L}^{-1}}\right)$ in 0.5 mol. $\mathrm{L}^{-1} \mathrm{HCl}$. Fig.(3) shows the various spectrum obtained for (a) $\mathrm{BCF}$, (b) $\mathrm{Fe}$ (II)$\left[\mathrm{Fe}(\mathrm{CN})_{6}\right]^{4-}-\mathrm{H}_{3} \mathrm{O}^{+}$system and (c) $\mathrm{BCF}-\mathrm{Fe}(\mathrm{III})-$ $\left[\mathrm{Fe}(\mathrm{CN})_{6}\right]^{4-}-\mathrm{H}_{3} \mathrm{O}^{+}$system. It shows the disappearance of both absorption maxima of $\mathrm{BCF}$ and response from $\mathrm{Fe}(\mathrm{II})-\left[\mathrm{Fe}(\mathrm{CN})_{6}\right]^{4-}$ $\mathrm{H}_{3} \mathrm{O}^{+}$system. It might be attributed to the total consumption of both reactant and reaction of $\mathrm{BCF}$ with $\mathrm{Fe}(\mathrm{II})$ in acidic medium to form $\mathrm{Fe}(\mathrm{III})$ then reacted it with $\mathrm{K}_{4}\left[\mathrm{Fe}(\mathrm{CN})_{6}\right]$ to form blue complex (P.B) which gave $\lambda_{\max }$ at $700 \mathrm{~nm}$.

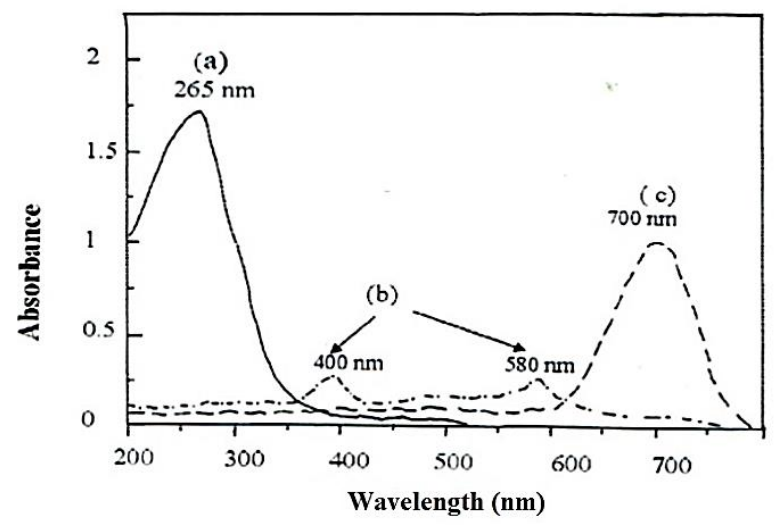

Fig.(3): Absorbance spectra for the determination of BCF.

a: Absorbance spectra(-) for BCF.

b: Absorbance spectra (- - - • ) for $\mathrm{Fe}(\mathrm{II})-[\mathrm{Fe}(\mathrm{CN}) 6]^{-4}-$ $\mathrm{H}_{3} \mathrm{O}^{+}$.

c: Absorbance spectra ( - - for BCF - Fe(II)-

$[\mathrm{Fe}(\mathrm{CN}) 6]^{-4}-\mathrm{H} 3 \mathrm{O}^{+}$system .

\section{Optimization of experimental conditions Chemical variable Effect of $\mathrm{Fe}(\mathrm{II})$ concentration:}

Series $0-15$ mmol.L $\mathrm{L}^{-1}$ of $\mathrm{Fe}$ (II) were prepared at concentration of potassium hexacyano ferrate(II) of $3 \mathrm{mmol} . \mathrm{L}^{-1}$ and using a preliminary concentration of $\mathrm{BCF} 10$ mmol. $\mathrm{L}^{-1}$ in $0.05 \mathrm{~mol} . \mathrm{L}^{-1} \mathrm{H}_{2} \mathrm{SO}_{4}$ as a carrier stream. Fig.(4) shows that 5 mmol. $\mathrm{L}^{-1}$ of $\mathrm{Fe}(\mathrm{II})$ is a suitable optimum concentration while at a concentration above this, distortion of the peak is observed, which might be due to small particles that may adhere on the glass wall.

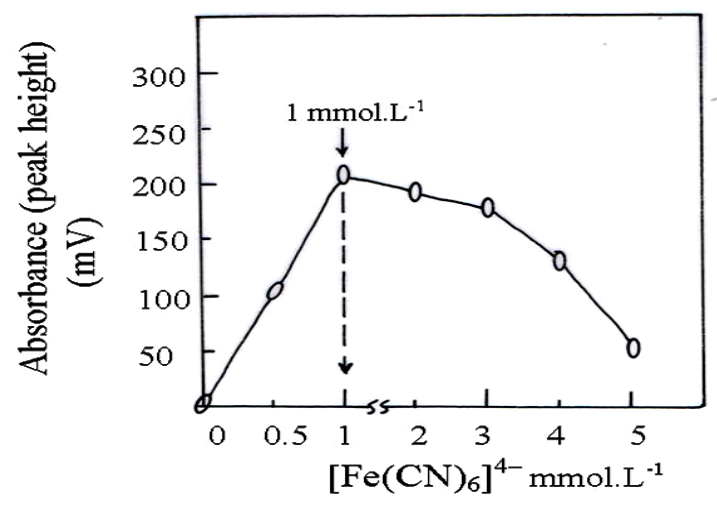

Fig.(4): Effect of variation of iron(II) concentration on absorbance for P.B complex, [BCF]: 10 mmol. $L^{-1}, 100 \mu L$.

Effect of variation of hexacyano iron(II) concentration on the absorbance of the prussion blue formation

A series (0-5) mmol. $\mathrm{L}^{-1}$ of hexacyano iron(II) solutions were prepared at optimum constant concentration of $\mathrm{Fe}(\mathrm{II})$ of $5 \mathrm{mmol} . \mathrm{L}^{-1}$ and using a chosen concentration of $\mathrm{BCF} 10$ mmol. $\mathrm{L}^{-1}$. Fig.(5) shows that $1 \mathrm{mmol} \cdot \mathrm{L}^{-1}$ of $\mathrm{K}_{4}\left[\mathrm{Fe}(\mathrm{CN})_{6}\right]$ is a suitable optimum concentration while at a concentration above this a wide broad peaks were obtained, this might be 
attributed to inner filter effect due to probably precipitated particulate of the complex.

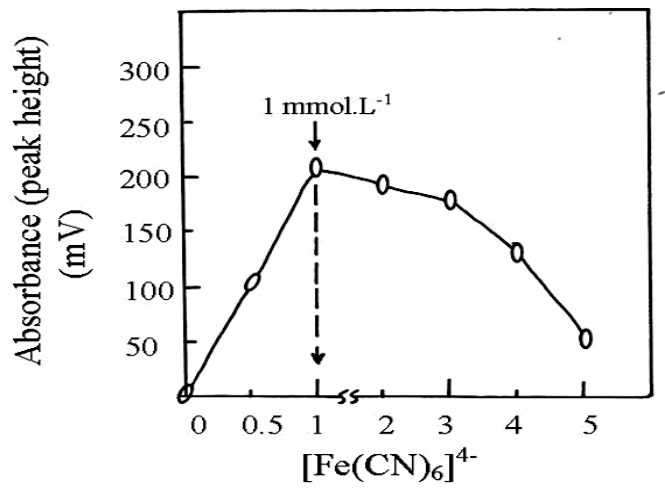

Fig.(5): Effect of variation of $\left[\mathrm{Fe}(\mathrm{CN})_{6}\right]^{4}$ concentration on determination of BCF (10 mmol. $\left.L^{-1}\right), 100 \mu L$.

Effect of acidic medium on the absorbance of the prussion blue formation

The oxidation of $\mathrm{Fe}$ (II) with $\mathrm{BCF}$ was studied in different acidic media (nitric, hydrochloric and sulphuric acid) at a series of concentration (0.01- 0.1) mol. $\mathrm{L}^{-1}$ in addition to the aqueous phase medium. The results are depicted in Fig.(6). In which that nitric acid increases absorbance which might be explained as it is a powerful oxidizing agent in addition to BCF drug effect. While using sulphuric acid absorbance is increases which might be explained to yielding immediately the coloured species on the basis of the outcome of the results obtained from this section, sulphuric acid medium with concentration $(0.01)$ mol. $\mathrm{L}^{-1}$ was chosen as optimum medium to conduct the reaction pattern.

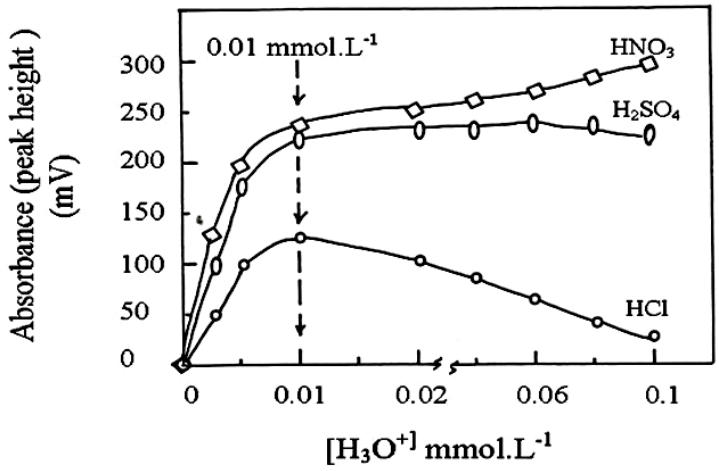

Fig.(6): Effect of type and concentration of acidic $\left(\mathrm{HNO}_{3}, \mathrm{H}_{2} \mathrm{SO}_{4}, \mathrm{HCl}\right)$ on absorbance of $P . B$ complex for determination of BCF (10 mmol. $\left.L^{-1}\right), 100 \mu L$.

\section{Physical parameters}

Flow rate effect

Using optimum concentration of the reactant, $\mathrm{Fe}(\mathrm{II}) \quad\left(5 \mathrm{mmol} . \mathrm{L}^{-1}\right), \mathrm{K}_{4}\left[\mathrm{Fe}(\mathrm{CN})_{6}\right]$ $\left(1 \mathrm{mmol} . \mathrm{L}^{-1}\right)$ and using a chosen concentration $\left(10\right.$ mmol.L $\left.{ }^{-1}\right)$ of BCF with the injected sample volume of $100 \mu \mathrm{L}$ at a variable flow rate as tabulated in table 1and Fig.(7). The results shown that the best flow rate for both lines of $\mathrm{Fe}(\mathrm{II})$ and $\mathrm{K}_{4}\left[\mathrm{Fe}(\mathrm{CN})_{6}\right]$ is $\left(1.5 \mathrm{~mL} \cdot \mathrm{min}^{-1}\right)$ and $\left(1.2 \mathrm{~mL} \cdot \mathrm{min}^{-1}\right)$ for the carrier stream.

Table (1)

Effect of the variation of flow rate on absorbance of P.B complex.

\begin{tabular}{|c|c|c|c|c|}
\hline \multirow{2}{*}{$\begin{array}{c}\text { Peristaltic } \\
\text { pump } \\
\text { speed }\end{array}$} & \multicolumn{3}{|c|}{ Flow rate $\left(\mathrm{mL} \cdot \mathrm{min}^{-1}\right)$} & \multirow{2}{*}{$\begin{array}{c}\text { Absorbance } \\
(\mathbf{m v}) \mathrm{n}=\mathbf{3}\end{array}$} \\
\hline & $\mathrm{Fe}(\mathrm{II})$ & {$\left[\mathrm{Fe}(\mathrm{CN})_{6}\right]^{-4}$} & $\begin{array}{l}\text { carrier } \\
\text { stream }\end{array}$ & \\
\hline 5 & 0.9 & 0.9 & 0.7 & 80 \\
\hline 10 & 1 & 1 & 0.9 & 100 \\
\hline 15 & 1.3 & 1.3 & 1.0 & 190 \\
\hline 20 & 1.5 & 1.5 & 1.2 & 230 \\
\hline 25 & 1.9 & 1.9 & 1.6 & 225 \\
\hline 30 & 2.3 & 2.3 & 1.9 & 175 \\
\hline
\end{tabular}

It was noticed that at low flow rate there is an increase in dilution and dispersion, while at higher speed due to the departure of the reactant from flow cell prior to the completion of reaction.

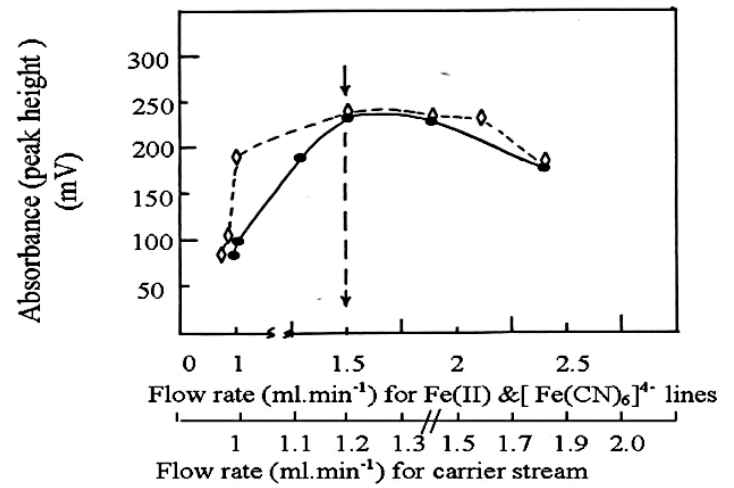

Fig.(7): Flow rate variation effect on the absorbance at optimum concentration parameters, $100 \mu \mathrm{L}$ (sample volume), [BCF]: 10 mmol. $L^{-1}$.

\section{Effect of sample volume}

Using the optimum parameters achieved in previous section. Variable sample volume (80, 100, 150, $200 \mu \mathrm{L})$ were injected. The data obtained were plotted as shown in Fig.(8) 
showing that the optimum sample volume is $(100 \mu \mathrm{L})$ given a high of response and regular. Using larger volume i.e. $>100 \mu \mathrm{L}$ it gave a slight higher response and irregular.

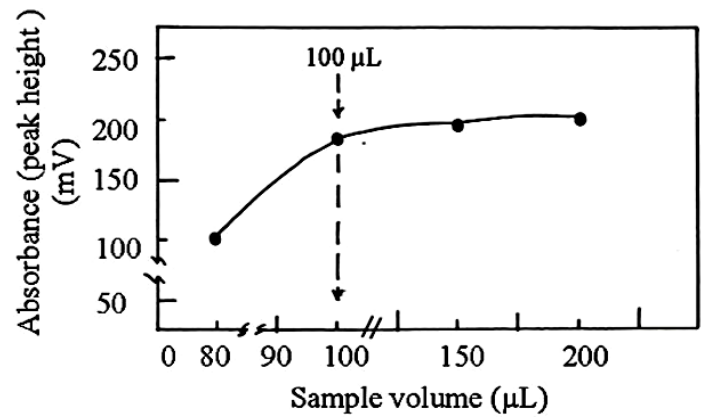

Fig.(8): Effect of variation of sample volume on absorbance of $P . B$ complex, [BCF]: 10 mmol. $\mathrm{L}^{-1}$.

Table (2)

Summery of calibration graph results for the determination of BCF.

\begin{tabular}{|c|c|c|c|c|c|}
\hline $\begin{array}{c}\text { Practical } \\
\text { measured } \\
\text { concentration } \\
\text { mmol.L } \\
\end{array}$ & $\begin{array}{c}\text { calibration } \\
\text { graph } \\
\text { concentration } \\
\text { mmol.L }^{-1} \\
\end{array}$ & $\begin{array}{c}\text { Linear regression } \\
\text { equation } \\
\mathbf{y}^{\wedge}(\mathrm{mv})=\mathbf{a}+\mathbf{b}[\mathrm{BCF}] \\
\text { mmol.L }^{-1} \\
\end{array}$ & $\mathbf{r}^{2} \%$ & $t_{\text {tab. }}$ & $\begin{array}{c}\mathbf{t}_{\text {cal. }}=\frac{|r| \sqrt{n-2}}{\sqrt{1-r^{2}}} \\
\text { at } 95 \%\end{array}$ \\
\hline $0.01-50$ & $0.05-25$ & $\begin{array}{c}20.40+19.12[\mathrm{BCF}] \\
\mathrm{mmol}^{-\mathrm{L}^{-1}}\end{array}$ & $\begin{array}{c}0.9972 \\
99.46 \%\end{array}$ & \multicolumn{2}{|c|}{$2.201 \ll 44.83$} \\
\hline
\end{tabular}

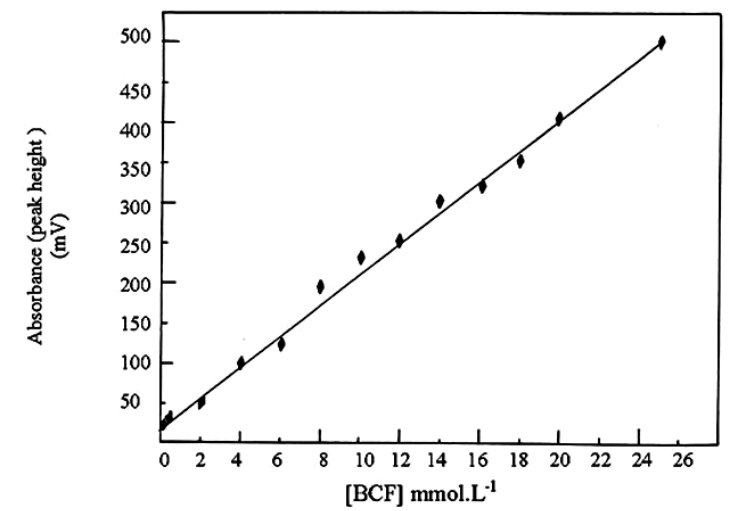

Fig.(9): Effect of variation of BCF concentration on absorbance at optimum conditions: BCF (variation of conc.) - Fe(II) $\left(5 \mathrm{mmol} . \mathrm{L}^{-1}\right)-\left[\mathrm{Fe}(\mathrm{CN})_{6}\right]^{-4}\left(1 \mathrm{mmol} . \mathrm{L}^{-1}\right)-$ $\mathrm{H}_{3} \mathrm{O}^{+}\left(\mathrm{H}_{2} \mathrm{SO}_{4}\left(0.01\right.\right.$ mol.L $\left.\left.{ }^{-1}\right)\right)$.

\section{Limit of detection}

Detection limit of BCF was conducted through three methods as tabulated in Table(3) at injected sample volume of $100 \mu \mathrm{L}$, also L.O.Q was reported.
Variation of absorbance versus concentration of BCF

Various concentrations $(0.01-50) \mathrm{mmol} . \mathrm{L}^{-1}$ $\mathrm{BCF}$ were prepared using the parameters established above. Each measurement were repeated three times. The absorbance of the average peak height (mv) was plotted against the concentration of BCF (Figure 9). A straight line graph from $(0.05-25) \mathrm{mmol}^{-\mathrm{L}^{-1}}$ of $\mathrm{BCF}$ was obtained. Above $25 \mathrm{mmol} . \mathrm{L}^{-1}$ the value for correlation coefficient will deviated from linearity. The obtained results were tabulated in Table (2). 
Table (3)

Limit of detection of quantitation for $B C F$ at optimum parameter.

\begin{tabular}{|c|c||c||c|}
\hline $\begin{array}{c}\text { General dilution for the } \\
\text { minimum concentration }\end{array}$ & $\begin{array}{c}\text { Based on the slope } \\
\mathbf{X}=\frac{\mathbf{3 S B}}{\text { slope }}\end{array}$ & $\begin{array}{c}\text { Linear equation } \\
\mathbf{y}^{\wedge}(\mathbf{m v})=\mathbf{y}_{\mathbf{B}}+\mathbf{3 S}_{\mathbf{B}}\end{array}$ & L.O.Q $=\mathbf{y}^{\wedge}=\mathbf{y}_{\mathbf{B}}+\mathbf{1 0 S}_{\mathbf{B}}$ \\
\hline \hline $10 \mu \mathrm{mol} . \mathrm{L}^{-1}$ & $16 \mu \mathrm{mol} . \mathrm{L}^{-1}$ & $0.29 \mathrm{mmol} . \mathrm{L}^{-1}$ & $1.05 \mathrm{mmol} . \mathrm{L}^{-1}$ \\
\hline
\end{tabular}

$\mathrm{x}=$ value of L.O.D based on slope.

$\mathrm{s}_{\mathrm{B}}=$ standard deviation of blank solution.

$\mathrm{y}_{\mathrm{B}}=$ response for the blank solution.

\section{Repeatability}

The work has been conducted in this project was characterized by high precision with good repeatability since the relative standard deviation (RSD) was very small. Table (4) shows the repeatability for the result obtained for the variable concentration of BCF. The response profile at concentration 4, 10 mmol.L $\mathrm{L}^{-1}$ of six successive injected sample measurements as shown in Fig.(10).

Table (4)

Repeatability for the determination BCF using P.B complex.

\begin{tabular}{|c|c|c|c|c|}
\hline $\begin{array}{c}\text { BCF }] \\
\text { mmol.L }^{-1}\end{array}$ & n & $\begin{array}{c}\text { Mean } \\
\overline{\mathbf{y}}_{\mathbf{i}}(\mathrm{mv}) \\
\end{array}$ & $\sigma_{n-1}$ & RSD $\%$ \\
\hline 4 & 6 & 100 & 0.98 & 0.98 \\
\hline 10 & 6 & 230 & 1.28 & 0.56 \\
\hline 20 & 5 & 400 & 2.32 & 0.58 \\
\hline
\end{tabular}
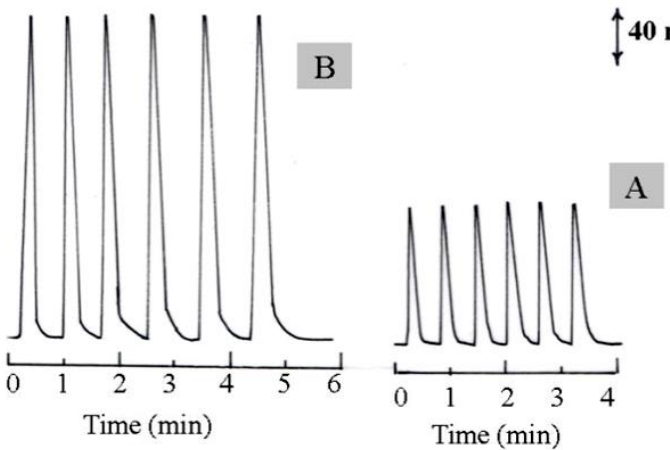

Fig.(10): Successive repeatable measurement for BCF; A: 4 mmol. $L^{-1}$, B: 10 mmol. $L^{-1}$.

\section{Analysis of pharmaceutical preparation}

The proposed method achieved in this work was used for the analysis of BCF in pharmaceutical preparation and was compared with the official method ${ }^{(4)}$. Thirteen tablets were weight, crushed and grinded. Tablets containing $10 \mathrm{mg}$ of $\mathrm{BCF}$ were weighted $3.3813 \mathrm{~g}$ (213.6 $\mathrm{mg}$ active ingredient) (10 mmol. $\mathrm{L}^{-1}$ ) from pharmaceutical preparation, dissolved in a little water, filtration to get ride of undissolved materials and completed the volume to $100 \mathrm{~mL}$ with distilled water. $10 \mathrm{~mL}$ was drown to each of five $25 \mathrm{~mL}$ volumetric flask followed by the addition of gradual volumes of standard BCF $(0,1,1.5,2,2.5) \mathrm{mL}$ of $100 \mathrm{mmol} . \mathrm{L}^{-1}$. Flask no. 1 is the sample. The measurement were conducted by proposed method and the results were mathematically treated for the standard addition method. The results were tabulated in Table (5) at confidence interval $95 \%$, paired t-test ${ }^{(16)}$ was used as shown in Table (6). The obtained results indication that there was no significant different between developed method (FIAspectrophotometer) with official method at $95 \%$ confidence level because $t_{\text {cal }}<t_{\text {tab }}$ 
Table (5)

Results for the determination BCF in pharmaceutical preparation using proposed method.

\begin{tabular}{|c|c|c|c|c|}
\hline $\begin{array}{l}\text { Pharmaceutical } \\
\text { Formulation, } \\
\text { content, country }\end{array}$ & $\begin{array}{l}\text { Weight of tablets (g) } \\
\bar{W} \pm \mathbf{t}_{0.025, \infty} \frac{\sigma n-1}{\sqrt{n}} \text { at } 95 \%\end{array}$ & $\begin{array}{c}\text { Based on } \\
\text { theoretical } \\
\text { content (mg) } \\
\end{array}$ & $\begin{array}{c}\text { Practical content } \\
\text { (mg) }\end{array}$ & Efficiency \% \\
\hline $\begin{array}{l}\text { Lioraz(10 mg) } \\
\text { Razi labs, Syria }\end{array}$ & $0.15825 \pm 0.0029$ & $10 \pm 0.183$ & $9.9 \pm 0.28$ & $99 \%$ \\
\hline
\end{tabular}

Table (6)

Paired t-test results for the proposed method with official method ${ }^{(4)}$ for the determination of BCF in pharmaceutical preparation.

\begin{tabular}{|c||c||c|c||c|c||}
\hline $\begin{array}{c}\text { Proposed method } \\
(\bar{x})\end{array}$ & $\begin{array}{c}\text { official } \\
\text { method } \\
(\boldsymbol{\mu})\end{array}$ & $\boldsymbol{\sigma}_{\mathrm{n}-\mathbf{1}}$ & $\mathbf{n}$ & $\left|\mathbf{t}_{\text {cal }}\right|=\frac{(\overline{\boldsymbol{x}}-\mu) \sqrt{\boldsymbol{n}}}{\boldsymbol{\sigma} \mathbf{n}-\mathbf{1}}$ & $\begin{array}{c}\mathbf{t}_{\text {tab }} \\
\text { at } \mathbf{9 5} \% \mathbf{n}-\mathbf{1}\end{array}$ \\
\hline \hline 9.9 & $10 \mathrm{mg}$ & 1.78 & 3 & \multicolumn{1}{|c|}{$1-0.0971=0.097 \ll 4.303$} \\
\hline \hline
\end{tabular}

\section{Conclusion}

The work presented in this research shows the capability of accepting an alternative method for the analysis and determination of BCF using the formation of Prussian blue with good repeatability and accepting linear dynamic range.

\section{Acknowledgements}

The author is grateful to Prof. Dr. Nagam S. Turkey Al-Awadie for providing her continuous support throughout the work.

\section{References}

[1] Seal Sc. Martindale, "The complete drug reference", $33^{\text {rd }}$ Ed., pharmaceutical press, London, 643, 1999.

[2] Tripathi. K. D., "Essentials of medical pharmacology", $5^{\text {th }}$ Ed., New Delhi, Jaypee brother's medical publishers, 316-318, 2003.

[3] British pharmacopoeia, "Her Majesty's stationery office", London, vol-1, 202, 2005.

[4] US pharmacopoeia NF, vol-23, 207, 2004.

[5] Sean, C., Sweetman, Martinal, "The complete Drug reference", $34^{\text {th }}$ Ed., 13861388, 2005.

[6] Abu MR., "Simple and rapid RP-HPLC determination of baclofen in human plasma with UV detection": application to a pharmacokinetic study, J.chromatogr B Biomed Sci Appl., 487,107-115, 1989.

[7] Nalluri B.N., Sushmitha K., Sunandana B. and Babu P., "Development and validation of RP-HPLC-PDA method for simultaneous estimation of baclofen and tizanidine in bulk and dosage forms", $J$. of applied pharmaceutical science, 2(7), 111-116, 2012.

[8] Sedat T. and Lale E., "Determination of baclofen in human plasma and urine by HPLC with fluorescence detection", Analyst, 120, 373-375, 1995.

[9] Miksa I.R. and Poppenga R.H., "Direct and rapid determination of baclofen (Lioresal) and Carisoprodol (Soma) in bovine serum by liquid chromatographyMass spectrometry", J.Anal.Toxical, 27 (5), 275-283, 2003.

[10] Islam T., Ferdous S., Jain P. and Reza H.M.; "Method development and validation of baclofen mouth dissolving tablets by UV spectroscopy", Europ.J. Appl.Sci.,5(1),711, 2013.

[11] Hosseinimehr S.J., Pourmorad F., Moshtaghi E. and Amini M., "Colorimeteric determination of baclofen with ninhydrin reagent and compare with Hplc method in tablet", Asian J.Chem., 22(1), 522-526, 2010.

[12] Elbashir A.A., Ahmed A.A., Ahmed S.M.A. and Aboul-Enein H.Y., "1,2Naphthoquinone-4-sulphonic acid sodium salt (NQS) as an analytical reagent for the determination of pharmaceutical amine by spectrophotometry", Applied spectroscopy Reviews ,47, 219-232, 2012.

[13] Ahmed M., Rajesh M., Sathish K.S.A. and Maanasa Rajan B.N., "Zero order and 
first order derivative spectrophotometric methods for determination of baclofen in pharmaceutical formulation", Int. J. Chem Tech Res., 3(2), 933-937, 2011.

[14] Ludi A., "Prussian blue, an inorganic evergreen", Journal of chemical education 58, 1013, 1981.

[15] Shakir I.M.A., Turkei N.S. and AlAwady M.J., "New approach for the online determination of paracetamol using merging zone-continuous flow injection analysis via home made photometric based on $704 \mathrm{~nm}$ LED and a photo silicon mini detector", National Journal of chemistry, 39, 455-468, 2010.

[16] Miller J.C. and Miller J.N., "Statistics for Anal. Chem"., $2^{\text {nd }}$ Ed., John wily and sons., New York, 1997.

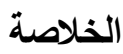

طورت طريقة طيفية بسيطة وسريعة وحساسة لتقدير عقار

باكلوفين في المستحضرات الصيدلانية من خلال اقتران تقنية التحليل بالحقن الجرياني مع المتحسس الطيفي. استتدت

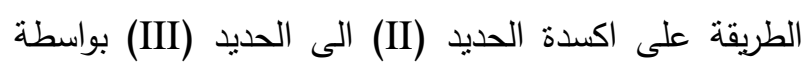

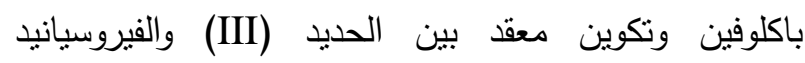
البوتاسيوم في الوسط الحامضي سجلت الامتصاصية للزرقة البروسية (prussian blue) عند 700 نانومينز • تم دراسة الطية الظروف الفيزيائية والكيميائية للتفاعل. مدى الخطية لدنحني

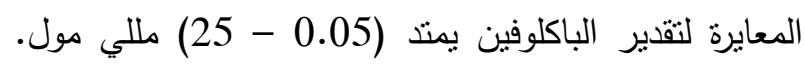

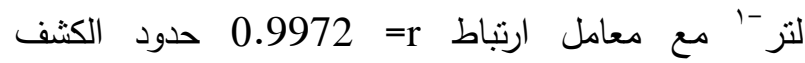
(S/N=3) 1.05 L.O.Q

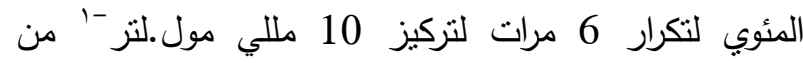
الباكلوفين هو 1.3 \% لانموذج محقن بحجم 100 مايكرولتر . طبقت الطريقة بنجاح لتقدير باكلوفين في أحد المستحضرات

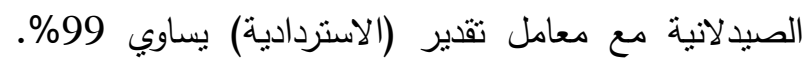
استخدم اختبار t- المزدوج وتبين أنه لايوجد فرق جوهري بين

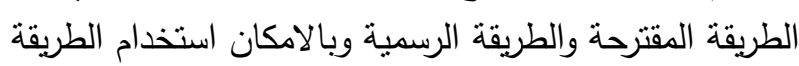
المقترحة كطريقة تحليلية بديلة. 